\title{
Temperature and Water Stress Effects on Growth of Tropical Grasses
}

\author{
D.H. BADE, B.E. CONRAD, AND E.C. HOLT
}

\begin{abstract}
Coastal bermudagrass (Cynodon dactylon (L.) Pers.) and Kleingrass "75" (Panicum coloratum $L$.) were grown under controlled environments to evaluate the effects of high growth temperatures and water stress on forage growth. Plants were grown under a controlled environment with $14 / 10$ hour day/night temperatures of $30 / 20,35 / 25$, and $40 / 30^{\circ} \mathrm{C} ; 2$ water regimes; and 3 stages or ages of regrowth at harvest. High growth temperatures significantly $(P<0.05)$ increased dry matter yield and accelerated tiller number and the maturation rate of the plants. Significant $(P<0.05)$ increases in leaf area, weight per tiller, and plant height were observed as growth temperatures were increased. Reduction of number of tillers per pot due to water stress reduced dry matter yields approximately $38 \%$. The percent leaf was greater for the water-stressed plants than for the well-watered plants, but the leaf area per plant was less due to reduction of growth and delayed maturation. Dry matter yield of water-stressed plants grown under higher temperatures increased more than corresponding wellwatered plants as a result of increased rate of stem elongation and leaf development. Though water-stressed plants were shorter and had less leaf area than well-watered plants, the relative increase in both height and leaf area at higher temperatures of stressed plants was greater than well-watered plants. Apparently supraoptimal temperature $\left(40^{\circ} \mathrm{C}\right)$ does not have a negative effect on yield in the presence or absence of moisture stress.
\end{abstract}

Reduction of digestible dry matter content has been reported for warm-season tropical grasses sampled under conditions of high temperature and water stress (Holt 1975, Pitman et al. 1981, Wilson 1981). Environmental stresses also affect growth rates and yields of grasses. Optimum temperatures for growth of tropical grasses are 30 to $35^{\circ} \mathrm{C}$ during the day and 25 to $30^{\circ} \mathrm{C}$ at night (Dirven and Deinum 1977, Ivory and Whiteman 1978). Optimum temperature results in an increased rate of stem elongation and leaf appearance (Dirven and Deinum 1977) and an increase of the number of tillers and of leaves per tiller. An increase in area per leaf and leaf area per plant also contributes to the greater production.

Conversely, water stress in tropical grasses reduces yield ( $\mathrm{Ng}$ et al. 1975, Wilson et al. 1976), slows cell enlargement and stem elongation, and reduces leaf area and the shoot/root ratio. High temperature can accentuate the rate of water loss, plant water deficits, and water stress. Although mid-summer sampling of warm-season grasses has facilitated evaluation of the combined effects of high temperatures and water stress, the independent effects of high temperature and water stress, and their interaction, remain to be quantified in controlled environments. Henderson and Robinson (1982) reported the effects of growth temperatures on yield of tropical grasses under 2 watering regimes, but the effects on yield components were not reported. In addition, growth temperatures reported to date generally have not exceeded $35^{\circ} \mathrm{C}$ in most studies, yet summer daytime temperature extremes in the Southwestern United States commonly exceed $35^{\circ} \mathrm{C}$.

The objective of this study was to quantify the independent effects of high growth temperature and water stress, and their interaction, on yield and growth components of Coastal bermudagrass and Kleingrass 75 .

\footnotetext{
Authors are former instructor, associate professor, and professor, Department of Soil and Crop Science, Texas A\&M University, respectively. D.H. Bade is currently Area Extension Agronomist, Texas Agricultural Extension Service, Bryan 77801.

Manuscript accepted December 19, 1984.
}

\section{Materials and Methods}

Coastal bermudagrass, a sod-type grass, and Kleingrass 75 kleingrass, a bunch-type grass, were selected for study. Kleingrass plants were established from tillers of a single plant. Bermudagrass plants were propagated using core samples taken from an established sod. Soil was washed from the roots of the tillers or cores and the grasses established in $20-\mathrm{cm}$ diameter ( 3.65 liter) polyethylene pots containing equal dry weights of potting soil. Potted plants were grown under greenhouse conditions prior to initiation of experiments under controlled conditions.

Prior to the start of the experimental period, plants were randomly assigned to treatments and placed in a $38-\mathrm{ft}^{2}$ plant growth chamber for a 3-week adjustment period. An irradiance at the top of the plants was provided by 16 sodium vapor lams ( 180 watt bulbs) at $1000 \mathrm{Mol} \mathrm{m}^{-2} \mathrm{~S}^{-1} \mathrm{PAR}$.

A step change of irradiance comprised the first and final hour of a 14-hour photoperiod. Relative humidity was maintained in a range of 64 to $70 \%$ by floor mounted humidifiers controlled by a wet bulb switch. The duration of day/night temperatures $\left({ }^{\circ} \mathrm{C}\right)$ of $30 / 20,35 / 25$, and $40 / 30$ coincided with the photoperiod duration.

Treatment combinations within each temperature regime consisted of 2 water regimes and three harvest stages or age of regrowth. The temperature regimes, considered as main blocks, were conducted over time and each temperature regime repeated once (Hammer and Urquhart 1979). Within each temperature regime, subplots consisted of 2 species, Coastal bermudagrass and Kleingrass 75 . Superimposed on each species in a random arrangement were all combinations of 2 watering levels (described below) and 3 stages and/or age of harvest. Individual treatment combinations were replicated 3 times. Plants (pots) were rerandomized as to treatments and position for each temperature regime.

Three harvests were made, each on different plants, at specified morphological stages and/or chronological ages for watered and water-stressed plants. Harvests were made (1) when 5 fully developed leaves appeared on 3 separate tillers per pot, (2) at 21 days of regrowth, and (3) at flowering or 3 separate tillers per pot of kleingrass. Bermudagrass did not flower, thus it was harvested at the same time as kleingrass plants in the flowering stage. Wellwatered and water-stressed plants were harvested independently of cach other. Temperature and water-stress trcatments were compared for the same ontogenetic stage and/or same date of harvest.

A moderate water stress was implemented by watering twice daily by pot weight to obtain a leaf xylem water potential of -1.2 to $-1.4 \mathrm{MPa}$. The well-watered plants were watered by pot weight to $80 \%$ of the field capacity to obtain a leaf xylem water potential of -0.8 to $-0.9 \mathrm{MPa}$. Distilled water was used for all treatments. Specific amounts of water to obtain desired leaf water potentials were determined during a 2-week adjustment period for each temperature regime by measuring leaf xylem water potential just prior to the beginning of the light period. Leaf xylem water potentials were determined with a hydraulic leaf press and monitored throughout the experimental period.

Fertilizer was supplied in equal amounts to all plants using a modified Hoagland's solution. Stock solutions were combined to provide $130 \mathrm{mg}$ nitrogen, $123 \mathrm{mg}$ potassium, $27 \mathrm{mg}$ phosphorus, 99 $\mathrm{mg}$ calcium, $16.5 \mathrm{mg}$ magnesium, $21 \mathrm{mg}$ sulfur, and required micronutrients per pot. All pots were leached with distilled water between experimental periods. Plant canopy height at harvest, 
days of regrowth to harvest, and leaf xylem water potentials were measured. Plant tops were removed to leave a 5-cm stubble and separated into leaf (lamina) and stem (leaf sheath, stem and any inflorescences) fractions. Leaf area and number of tillers per pot were recorded. Leaf and stem fractions were dried at $100^{\circ} \mathrm{C}$ for 2 hours, followed by drying at $60^{\circ} \mathrm{C}$ for 48 hours to determine dry matter yields.

Analysis of variance, and analysis of the 2-way interactions by contrast were used to analyze the data.

\section{Results and Discussion}

Accelerated ontogenetic development occurred with increasing growth temperature from $30 / 20^{\circ} \mathrm{C}$ to $35 / 25^{\circ} \mathrm{C}$ for both wellwatered plants and water-stressed plants (Table 1). Temperatures

Table 1. Days of regrowth required for ontogenetic stage of harvest with various temperature and water regimes of kleingrass.

\begin{tabular}{|c|c|c|c|}
\hline \multirow{2}{*}{$\begin{array}{l}\text { Ontogenetic stage of } \\
\text { harvest }\end{array}$} & \multicolumn{3}{|c|}{ Temperature $^{\circ} \mathrm{C}$ (day $/$ night) } \\
\hline & $30 / 20$ & $35 / 25$ & $40 / 30$ \\
\hline & \multicolumn{3}{|c|}{ days of regrowth } \\
\hline $\begin{array}{l}\text { 5th leaf stage } \\
\text { Well-watered } \\
\text { Water-stressed }\end{array}$ & $\begin{array}{l}16 a^{1} B^{2} \\
20 a A\end{array}$ & $\begin{array}{l}10 \mathrm{~b} \mathrm{~B} \\
15 \mathrm{~b} \mathrm{~A}\end{array}$ & $\begin{array}{l}10.5 \text { b B } \\
14.5 \text { b A }\end{array}$ \\
\hline $\begin{array}{l}\text { Anthesis of kleingrass } \\
\text { Well-watered } \\
\text { Water-stressed }\end{array}$ & $\begin{array}{l}30 \text { a } \mathrm{B} \\
33 \text { a } \mathrm{A}\end{array}$ & $\begin{array}{l}21 \text { b B } \\
28 \text { b A }\end{array}$ & $\begin{array}{l}19 \text { c B } \\
25 \text { c A }\end{array}$ \\
\hline
\end{tabular}

'Means in each line followed by the same lower case letter are not significantly different at the 0.05 level of probability, based on Duncan's Multiple Range Test.

${ }^{2}$ Means for each stage/age average in a column followed by the same upper case letter are not significantly differently at the 0.05 level of probability, based on Duncan's Multiple Range Test.

above $35 / 25^{\circ} \mathrm{C}$ did not further reduce the time required to reach a specific stage. This increase in development rate with increasing temperatures to $35 / 25^{\circ} \mathrm{C}$ has been well documented (Dirven and Deinum 1977; Wilson and Ford 197.1, 1973).

Dry matter yields for both grass species were significantly $(P<0.05)$ affected by growth temperature, water trcatment, and harvest frequency (Table 2). With the exception of the 5-leaf stage, dry matter yields were significantly higher $(P<0.05)$ at the $40 / 30$ temperature regime for both the well-watered and the waterstressed treatments than at the $30 / 20$ temperature regime. This response was consistent for both grass species. With the exception of the early harvest, dry matter yields were higher $(P<0.05)$ for the well-watered than for the water-stressed plants at each temperature. Water stress reduced dry matter yields by 31 and $44 \%$ for bermudagrass and kleingrass, respectively. Pitman et al. (1981) reported similar decreases in dry matter yield of kleingrass grown under comparable degrees of constant water stress. The yield reduction is similar to the $40 \%$ reported by Wilson and $\mathrm{Ng}$ (1975) with recurring cycles of short-term water stress.

The greatest yield response to high temperatures occurred with plants under water stress (Fig. la). Well-watered plants showed little increase in yield above $35 / 25^{\circ} \mathrm{C} /$ while water-stressed plants showed a marked increase above $35 / 25^{\circ} \mathrm{C}$. High temperature might be expected to exaggerate the effect of water stress through increased rate of evapotranspiration, thereby further reducing yield due to water stress. While this pattern would likely occur under field conditions with intermittent rainfall, it did not occur with daily water increments to replace the moisture lost through evapotranspiration. Under these conditions a proportionately larger yield increase occurred at the highest temperature in stressed versus well-watered plants. The stressed plants had a slowed rate of ontogenetic development (Table 1). They have a higher leaf percent and they are shorter than their well-watered counterparts (lcss stcm elongation). Higher temperature may speed up stem elongation and flowering of the less-developed, stressed plants; whereas, stems have already elongated and stem growth rate is less responsive to temperatures for well-watered plants.
Table 2. Dry matter yield of two warm season perennial grasses as affected by growth temperature and water regime.

\begin{tabular}{|c|c|c|c|c|}
\hline \multirow{2}{*}{$\begin{array}{l}\text { Harvest stage/age and } \\
\text { water regime }\end{array}$} & \multicolumn{4}{|c|}{ Growth temperature, ${ }^{\circ} \mathrm{C}$ (day/night) } \\
\hline & $30 / 20$ & $35 / 25$ & $40 / 30$ & Average \\
\hline & \multicolumn{4}{|c|}{$\mathrm{g} /$ plant, bermudagrass } \\
\hline $\begin{array}{l}\text { Sth leaf stage } \\
\text { Well-watered } \\
\text { Water-stressed }\end{array}$ & $\begin{array}{l}1.9 \mathrm{a}^{1} \mathrm{~A}^{2} \\
1.4 \mathrm{~b} \mathrm{~A}^{2}\end{array}$ & $\begin{array}{l}1.9 \text { a } \mathrm{A} \\
1.5 \mathrm{~b} \mathrm{~A}\end{array}$ & $\begin{array}{l}2.5 \mathrm{a} \mathrm{A} \\
2.4 \mathrm{a} \mathrm{A}\end{array}$ & $\begin{array}{l}2.1 \mathrm{~A} \\
1.8 \mathrm{~A}\end{array}$ \\
\hline $\begin{array}{l}21 \text { days of regrowth } \\
\text { Well-watered } \\
\text { Water-stressed }\end{array}$ & $\begin{array}{l}3.1 \mathrm{~b} \mathrm{~A} \\
1.7 \mathrm{c} \mathrm{B}\end{array}$ & $\begin{array}{l}6.6 \mathrm{a} \mathrm{A} \\
2.9 \mathrm{~B} \mathrm{~b}\end{array}$ & $\begin{array}{l}7.0 \mathrm{a} \mathrm{A} \\
4.5 \mathrm{a} \mathrm{B}\end{array}$ & $\begin{array}{l}5.6 \mathrm{~A} \\
3.0 \mathrm{~B}\end{array}$ \\
\hline $\begin{array}{l}\text { Anthesis (of kleingrass) } \\
\text { Well-watered } \\
\text { Water-stressed }\end{array}$ & $\begin{array}{c}4.4 \mathrm{~b} \mathrm{~A} \\
2.5 \mathrm{c} \mathrm{B}\end{array}$ & $\begin{array}{l}6.1 \text { a A } \\
4.4 \text { b B }\end{array}$ & $\begin{array}{l}6.6 \text { a A } \\
5.8 \text { a B }\end{array}$ & $\begin{array}{l}5.7 \mathrm{a} \\
4.2 \mathrm{~B}\end{array}$ \\
\hline $\begin{array}{l}\text { Stage/age average } \\
\text { Well-watered } \\
\text { Water-stressed }\end{array}$ & $\begin{array}{l}3.1 \mathrm{~b} \mathrm{~A} \\
1.9 \mathrm{c} \mathrm{B}\end{array}$ & $\begin{array}{l}4.9 \mathrm{a} \mathrm{A} \\
2.9 \mathrm{~b} \mathrm{~B}\end{array}$ & $\begin{array}{l}5.4 \text { a A } \\
4.2 \text { a B }\end{array}$ & $\begin{array}{l}4.5 \mathrm{~A} \\
3.0 \mathrm{~B}\end{array}$ \\
\hline & \multicolumn{4}{|c|}{$\mathrm{g} /$ plant, kleingrass } \\
\hline $\begin{array}{l}\text { 5th leaf stage } \\
\text { Well-watered } \\
\text { Water-stressed }\end{array}$ & $\begin{array}{l}2.2 \mathrm{a} \mathrm{A} \\
1.9 \mathrm{a} \mathrm{A}\end{array}$ & $\begin{array}{l}2.1 \text { a } \mathrm{A} \\
1.5 \text { a } \mathrm{A}\end{array}$ & $\begin{array}{l}2.2 \text { a A } \\
2.2 \text { a A }\end{array}$ & $\begin{array}{l}2.2 \mathrm{~A} \\
1.9 \mathrm{~A}\end{array}$ \\
\hline $\begin{array}{l}21 \text { days of regrowth } \\
\text { Well-watered } \\
\text { Water-stressed }\end{array}$ & $\begin{array}{l}3.8 \mathrm{~b} \mathrm{~A} \\
1.7 \mathrm{~b} \mathrm{~B}\end{array}$ & $\begin{array}{l}5.9 \text { a A } \\
2.2 \text { b B }\end{array}$ & $\begin{array}{l}5.4 \text { a A } \\
3.3 \text { a B }\end{array}$ & $\begin{array}{l}5.0 \mathrm{a} \\
2.4 \mathrm{~B}\end{array}$ \\
\hline $\begin{array}{l}\text { Anthesis of kleingrass } \\
\text { Well-watered } \\
\text { Water-stressed }\end{array}$ & $\begin{array}{l}5.3 \mathrm{~b} \mathrm{~A} \\
3.0 \mathrm{~b} \mathrm{~B}\end{array}$ & $\begin{array}{l}6.3 \mathrm{a} \mathrm{A} \\
3.0 \mathrm{~b} \mathrm{~B}\end{array}$ & $\begin{array}{l}6.7 \text { a } A \\
4.4 \text { a B }\end{array}$ & $\begin{array}{l}6.1 \mathrm{~A} \\
3.5 \mathrm{~B}\end{array}$ \\
\hline $\begin{array}{l}\text { Stage/age average } \\
\text { Well-watered } \\
\text { Water-stressed }\end{array}$ & $\begin{array}{l}3.8 \mathrm{~b} \mathrm{~A} \\
2.1 \mathrm{~b} \mathrm{~B}\end{array}$ & $\begin{array}{l}4.8 \mathrm{a} \mathrm{A} \\
2.2 \mathrm{~b} \mathrm{~B}\end{array}$ & $\begin{array}{l}4.8 \text { a A } \\
3.3 \mathrm{a} \mathrm{B}\end{array}$ & $\begin{array}{l}4.5 \mathrm{~A} \\
2.5 \mathrm{~B}\end{array}$ \\
\hline
\end{tabular}

Means in each line followed by the same lower case letter are not significantly different at the 0.05 level of probability, based on Duncan's Multiple Range Test. 2Means for each stage/age average in a column followed by the same upper case letter are not significantly differently at the 0.05 level of probability, based on Duncan's Multiple Range Test.

Bermudagrass and kleingrass did not differ significantly $(P<0.05)$ in yield at each of the three growth temperatures though bermudagrass tended to have a higher yield at both the intermediate and high temperatures. The species by temperature interaction was significant $(P<0.05)$ suggesting a higher optimum temperature for bermudagrass.
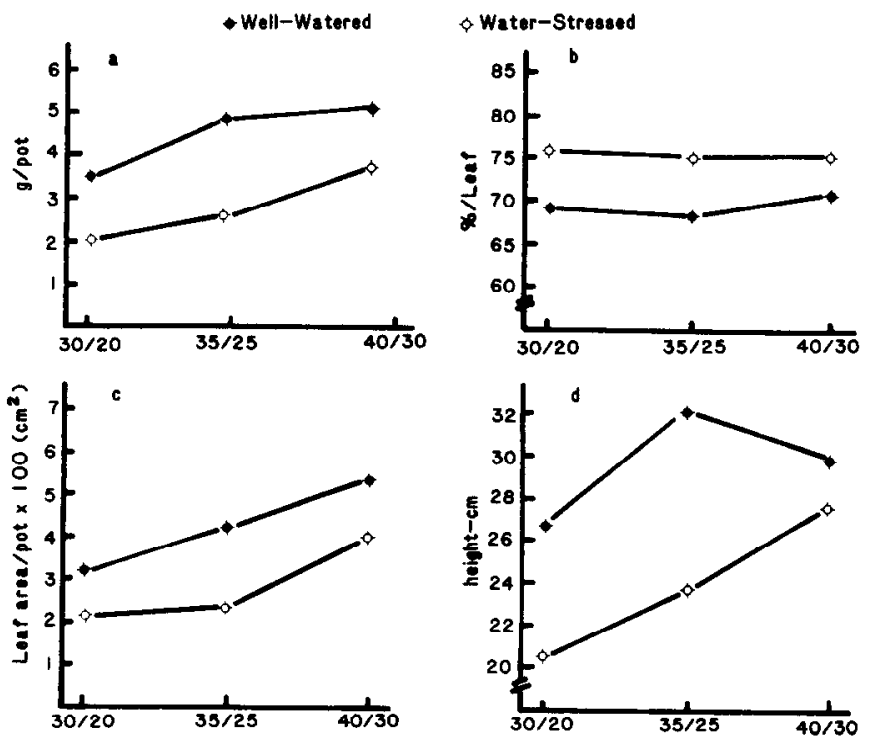

Day/Night Temperature $\left(^{\circ} \mathrm{C}\right)$

Fig. 1. Temperature and water stress effects on tropical grass growth components (average of both species). 
Bermudagrass and kleingrass yields were equal when wellwatered but kleingrass produced significantly less $(P<0.05)$ yield $(-17 \%)$ than bermudagrass when stressed. Thus, while kleingrass will survive and grow in lower rainfall areas than bermudagrass, it is not more efficient in water utilization under those conditions where bermudagrass will grow and survive.

Yield components were measured to provide a better understanding of the effects of temperature and moisture stress on yield. Total yield, weight/ tiller, leaf area/pot, and plant height increased as temperature increased. Total yield, tillers/pot, leaf area/pot, and plant height were less for water-stressed than for well-watered treatments (Fig. 1). Tillers/pot for bermudagrass were significantly $(P<0.05)$ greater than for kleingrass and the well-watered plants had a greater number of tillers than the water-stressed plants (Tables 3 and 4). Water stress decreased tillers/pot $(P<0.05) 20 \%$

Table 3. Yield components of kleingrass as affected by growth temperature and water regime.

\begin{tabular}{|c|c|c|c|}
\hline & \multicolumn{3}{|c|}{ Growth temperature ${ }^{\circ} \mathrm{C}$ (day/night) } \\
\hline & $30 / 20$ & $35 / 25$ & $40 / 30$ \\
\hline & \multicolumn{3}{|c|}{ tillers/pot -} \\
\hline \multicolumn{4}{|l|}{ Tillers/pot } \\
\hline $\begin{array}{l}\text { Well-watered } \\
\text { Water-stressed }\end{array}$ & $\begin{array}{l}26.3 \mathrm{~b}^{\prime} \mathrm{A}^{2} \\
14.6 \mathrm{a} \mathrm{B}\end{array}$ & $\begin{array}{l}29.0 \text { a A } \\
14.3 \text { a B }\end{array}$ & $\begin{array}{l}27.5 \text { a A } \\
14.5 \text { a B }\end{array}$ \\
\hline \multicolumn{4}{|l|}{ Weight/tiller } \\
\hline $\begin{array}{l}\text { Well-watered } \\
\text { Water-stressed }\end{array}$ & $\begin{array}{l}137.2 \mathrm{c} \mathrm{A} \\
114.8 \mathrm{c} \mathrm{B}\end{array}$ & $\begin{array}{l}165.5 \text { b A } \\
153.8 \text { b A }\end{array}$ & $\begin{array}{l}183.2 \text { a B } \\
270.5 \text { a A }\end{array}$ \\
\hline O Ieaf & & $\%$ leaf & \\
\hline $\begin{array}{l}\text { Well-watered } \\
\text { Water-stressed }\end{array}$ & $\begin{array}{l}76.5 \text { b B } \\
83.7 \text { a A }\end{array}$ & $\begin{array}{l}75.0 \text { b B } \\
83.7 \text { a A }\end{array}$ & $\begin{array}{l}82.3 \text { a B } \\
86.8 \text { a } A\end{array}$ \\
\hline \multicolumn{4}{|l|}{ Leaf area } \\
\hline $\begin{array}{l}\text { Well-watered } \\
\text { Water-stressed }\end{array}$ & $\begin{array}{l}386.2 \text { c A } \\
262.8 \text { b B }\end{array}$ & $\begin{array}{l}511.2 \mathrm{~b} \mathrm{~A} \\
258.2 \mathrm{~b} \mathrm{~B}\end{array}$ & $\begin{array}{l}683.7 \text { a A } \\
477.3 \text { a B }\end{array}$ \\
\hline \multicolumn{4}{|l|}{ Plant height } \\
\hline $\begin{array}{l}\text { Well-watered } \\
\text { Water-stressed }\end{array}$ & $\begin{array}{l}33.7 \text { с A } \\
23.2 \text { c B }\end{array}$ & $\begin{array}{l}39.7 \text { a A } \\
27.5 \text { b B }\end{array}$ & $\begin{array}{l}38.3 \text { b A } \\
36.0 \text { a B }\end{array}$ \\
\hline
\end{tabular}

'Means in each line followed by the same lower case letter are not significantly different at the 0.05 level of probability, based on Duncan's Multiple Range Test.

${ }_{2}^{2}$ Means for each yield component in a column followed by the same upper case letter not significantly different at the 0.05 level of probability, based on Duncan's Multiple Range Test.

and $46 \%$ for bermudagrass and kleingrass, respectively. Tillers/pot for bermudagrass increased as growth temperature increased from $30 / 20$ to $35 / 25$ for both well-watered and water-stressed plants (Table 4). Tillers/pot were not affected by growth temperature for water-stressed kleingrass plants. (Table 3).

The increase in dry matter yield with increased temperature (Fig. la) cannot be explained by temperature effects on tillers/pot per se. Although increased temperature affected tiller/pot of bermudagrass, the response pattern was not the same as for dry matter yield and, therefore, does not account for the yield response. Tillers/pot increased significantly from $30 / 20$ to $35 / 25$ but tended to decrease when temperature was increased to $40 / 30^{\circ} \mathrm{C}$, whereas yield continued to increase to the highest temperature. The reduction in dry matter yield under water stress can be related to the reduction $(P<0.05)$ in tillers/pot.

Weight per tiller was greater $(P<0.05)$ for kleingrass than bermudagrass at all temperature regimes, water treatments, and harvest stages or age (Tables 3 and 4). Production of dry matter per tiller increased significantly with increased growth temperature in both species under both moisture levels. Most of the increase in yield of water-stressed plants when temperature was increased to
Table 4. Yield components of bermudagrass as affected by growth temperature and water regime.

\begin{tabular}{|c|c|c|c|}
\hline & \multicolumn{3}{|c|}{ Growth temperature ${ }^{\circ} \mathrm{C}$ (day/night) } \\
\hline & $30 / 20$ & $35 / 25$ & $40 / 30$ \\
\hline & 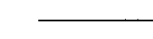 & tiller/pot- & - \\
\hline $\begin{array}{l}\text { Tillers/pot } \\
\text { Well-watered } \\
\text { Water-stressed }\end{array}$ & $\begin{array}{l}122.8 \mathrm{~b}^{1} \mathrm{~A}^{2} \\
92.2 \mathrm{~b} \mathrm{~B}\end{array}$ & $\begin{array}{l}146.8 \text { a A } \\
109.8 \text { a B }\end{array}$ & $\begin{array}{l}139.0 \mathrm{a} \mathrm{A} \\
103.5 \mathrm{ab} \mathrm{B}\end{array}$ \\
\hline $\begin{array}{l}\text { Weight/tiller } \\
\text { Well-watered } \\
\text { Water-stressed }\end{array}$ & $\begin{array}{l}20.8 \mathrm{c} \mathrm{A} \\
15.9 \mathrm{c} \mathrm{A}\end{array}$ & $\begin{array}{l}33.4 \text { b A } \\
26.4 \text { b A }\end{array}$ & $\begin{array}{ll}48.0 \mathrm{a} & \mathrm{A} \\
45.4 \mathrm{a} & \mathrm{B}\end{array}$ \\
\hline $\begin{array}{l}\text { Well-watered } \\
\text { Water-stressed }\end{array}$ & $\begin{array}{l}61.8 \text { a B } \\
68.0 \text { a A }\end{array}$ & $\begin{array}{l}61.7 \text { a B } \\
66.8 \text { a A }\end{array}$ & $\begin{array}{l}60.3 \mathrm{a} \\
63.8 \mathrm{a}\end{array}$ \\
\hline $\begin{array}{l}\text { Leaf area } \\
\text { Well-watered } \\
\text { Water-stressed }\end{array}$ & $\begin{array}{l}250.8 \text { c A } \\
158.0 \text { c B }\end{array}$ & $\begin{array}{l}332.8 \text { b A } \\
211.5 \text { b B }\end{array}$ & $\begin{array}{l}397.7 \text { a } \\
330.0 \text { a }\end{array}$ \\
\hline $\begin{array}{l}\text { Plant height } \\
\text { Well-watered } \\
\text { Water-stressed }\end{array}$ & $\begin{array}{l}19.7 \text { c A } \\
17.7 \text { a A }\end{array}$ & $\begin{array}{l}24.7 \text { a A } \\
19.7 \text { a B }\end{array}$ & $\begin{array}{c}21.7 \text { b } \\
19.1 \text { a }\end{array}$ \\
\hline
\end{tabular}

${ }^{1}$ Means in each line followed by the same lower case letter re not significantly different at the 0.05 level of probability, based on Duncan's Multiple Range Test.

${ }^{2}$ Means for each yield component in a column followed by the same upper case letter are not significantly different at the 0.05 level of probability, based on Duncan's Multiple Range Test.

$40 / 30^{\circ} \mathrm{C}$ evidently is related to the concurrently increased weight per tiller. Ivory and Whiteman (1978) concluded that increased growth with increased temperature was due to weight per tiller and not number of tillers per pot. Dirven and Deinum (1977) also noted that heavy tillers occurred at high growth temperature in Brachiaria ruziziensis (Germain and Evard). These data show that the response in weight per tiller occurs at temperatures up to $40 / 30^{\circ} \mathrm{C}$ and the response is proportionately greater if the plants are water stressed.

Kleingrass was significantly higher $(P<0.05)$ in percent leaf than bermudagrass (Tables 3 and 4 ) and the 5th leaf stage was higher in percent leaf than later harvests (data not shown). Percent leaf was not significantly affected by growth temperature (Fig. lb). There was a significant increase in leaf percent of water-stressed plants over well-watered plants at all temperatures for kleingrass and at the 2 lower temperatures for bermudagrass, and this response is reflected in the average of species (Fig. 1b).

The leaf area per plant increased $(P<0.05)$ for both species as temperature increased. Leaf area for kleingrass was greater $(P<0.05)$ than that for bermudagrass and well-watered plants greater $(P<0.05)$ than water-stressed plants. Leaf area changes closely follow the changes in weight per tiller with a significant $(P<0.05)$ increase occurring with increased temperatures for both well-watered and water-stressed plants (Fig. Ic). As with weight per tiller, the largest increase in leaf area associated with temperature occurred under water stress as temperature was increased from $35 / 25$ to $40 / 30$ in both species (Table 3 and 4). Ivory and Whiteman (1978) concluded that the increase in leaf area with increased growth temperature was due to increased leaf size for all species rather than variation in the number of leaves per tiller. It seems possible that the same factor was involved in the leaf area increases in this study, though leaves per tiller were not determined.

The response of plant height to temperature differed for wellwatered and water-stressed plants (Fig. 1d). The increase of plant height as growth temperature increased from $30 / 20$ to $35 / 25$ for well-watered plants of both species correspond to the dry matter 
yield responses. This increase in plant height with increased temperature was the result of accelerated stem elongation (Dirven and Deinum 1977). Growth temperature had a significant effect on plant height of water-stressed kleingrass plants (Table 3) but not on bermudagrass (Table 4). The increase in weight per tiller in waterstressed kleingrass as temperature increased, and hence, increase in dry matter yield, was related to increased plant height from stem elongation and a greater leaf area. The increase in weight per tiller in water-stressed bermudagrass with increased temperature was not due to increased plant height, but was probably the result of increased lateral branching of existing tillers and increased leaf area. The absence of reproductive tillers with inflorescences in bermudagrass affected the difference in plant height response of the two species to growth temperature.

The reduction in dry matter yield from water stress was due more to a reduction in the number of tillers per plant than to the weight per tiller (Tables 3 and 4$)$. The significant $(P<0.05)$ reduction in plant height due to water stress indicates the overriding effect of water stress on stem elongation, even as temperature was increased. This study suggests that these tropical grasses are not actually stressed by supraoptimal temperatures up to $40^{\circ} \mathrm{C}$. Also, high temperature does not interact with moisture stress to exaggerate stress effects on the plant. In fact supraoptimal growth temperature combined with water stress seemed to result in a positive yield response under conditions where some soil moisture was available. While the general growth responses of Coastal bermudagrass and Kleingrass 75 were similar, individual growth components of the two species responded differently to high temperature and moisture stress.

\section{Literature Cited}

Dirven, J.G.P., and B. Deinum. 1977. The effect of temperature on the digestibility of grasses. Forage Res. 3:1-17.
Hammer, P. Allen, and N. Scott Urquhart. 1979. Precision and replication: critique II. p. 354-361. In: Controlled Environmental Guidelines for Plant Research. T.W. Tibbitts and T.T. Kozlowski(ed). Academic Press, Inc. New York, New York.

Henderson, M.S., and D.L. Robinson. 1982. Environmental influences on yield and in vitro true digestibility of warm season perennial grasses and the relationship to fiber components. Agron. J. 74:945-946.

Holt, E.C. 1975. Meeting the nutrient requirements of beef cattle with forage. p. 261-285. In: Forage Fed Beef: Production and Marketing Alternatives in the South, J.A. Studemann, D.L. Huffman, J.C. Purcell, and O.L. Walker (eds.). Bul. 220. So. Coop. Series.

Ivory, D.A., and P.C. Whiteman. 1978. Effect of temperature on growth of five subtropical grasses. I. Effect of day and night temperature on growth and morphological development. Aust. J. Plant Physiol. 5:131-148.

Ng, T.T., J.R. Wilson, and M.M. Ludlow. 1975. Influence of water stress on water relations and grown of a tropical $\left(\mathrm{C}_{4}\right)$ grass, Panicum maximum var. trichoglume. Aust. J. Plant Physiol. 2:581.

Pitman, W.D., D.M. Vietor, and E.C. Holt. 1981. Digestibility of kleingrass forage grown under moisture stress. Crop Sci. 21:951-953.

Wilson, J.R. 1981. Environmental nutritional factors affecting herbage quality. p. 11-131. In: Proceedings of an International Symposium (St. Lucia, Queensland, Australia). J. B. Hacker, (ed.). Commonwealth Agricultural Bureaux, Farmham Royal, UK.

Wilson, J.R., and C.W. Ford. 1971. Temperature influence on the growth, digestibility, and carbohydrate composition of two tropical grasses, Panicum maximum var. trichoglume and Setaria sphacelata and two cultivars of the temperate grass Lolium perenne. Aust. J. Agr. Res. 22:563-571.

Wilson, J.R., and C.W. Ford. 1973. Temperature influences on the in vitro digestibility and soluble carbohydrate accumulation of tropical and temperate grasses. Aust. J. Agr. Res. 24:187-198.

Wilson, J.R., and T.T. Ng. 1975. Influence of water stress on parameters associated with forage quality of Panicum maximum var. trichoglume. Aust. J. Agr. Res. 25:127-136.

Wilson, J.R., A.O. Taylor, and G.R. Dolby. 1976. Temperature and atmospheric humidity effects on cell wall content and dry matter digestibility of some tropical and temperate grasses. N.Z.J. of Agr. Res. 19:41-46.

\section{Associate Editorship-Journal of Range Management}

Nominees are being sought for 2 associate editorships which will be open in the coming year. Associate editors serve for 2 years with an optional 2-year renewal. Areas of expertise especially needed at present are plant physiology, reclamation and range improvements, sampling methodology in range research, and soils. Candidates selected will work with an associate editor for 3 months before taking over complete responsiblity in February 1986.

Nominees should have a strong and current background in research, be capable writers, and have had successful experience as reviewers. Associate editors are responsible for conducting the review of manuscripts and for accepting or rejecting manuscripts. The average yearly load is 20-30 manuscripts.

Nominations should be submitted before 15 September 1985, to the Editor, Journal of Range Management, 2760 West Fifth Avenue, Denver, CO 80204. The individual making the nomination should give his own name, the name, address, telephone number, and current position of the nominee as well as a description of his qualifications for the associate editorship. The nominator should ascertain that the individual would be willing to serve if selected. An Editorial Replacement Committee will select the associate editors subject to the approval of the Board of Directors.

The Socicty's journal both reflects the state of the professionand influences the course of the profession. Selection as an associate editor is, therefore, an honor and a responsiblity. 